\title{
A Review on Detecting and Characterizing Damage Mechanisms of Synthetic and Natural Fiber Based Composites
}

\author{
Noorshazlin Razali, ${ }^{\mathrm{a} *}$ Mohamed Thariq Hameed Sultan, ${ }^{\mathrm{a}}$, ${ }^{*}$ and Mohammad Jawaid ${ }^{\mathrm{b}}$ \\ The damage to composite structures caused by impact events is one of \\ the most critical behaviors that inhibit the widespread application of \\ composite material. As the application of synthetic and natural based \\ composite material increases over time, improved knowledge of \\ composite damage in areas such as automotive and aerospace is \\ exceedingly necessary. It is important to study and understand the \\ damage mechanism of composite structures to produce effective \\ designs. The failure caused by damage in structural design can result in \\ unintended consequences. Extensive research has been conducted to \\ detect impact damage in synthetic fiber. There are various methods to \\ identify and characterize the damage. This article provides a \\ comprehensive review of recent literature focusing on the broader scope \\ of impact damage and incipient thermal damage of synthetic and natural \\ fiber-based composites. In this report, the available research is reviewed \\ by considering all aspects related to damage in composite materials, \\ particularly the work done on detecting and characterizing damage \\ mechanisms of synthetic and natural fiber-based composites.
}

Keywords: Impact damages; Incipient thermal damages (ITD); Bio-composite; Natural fiber

Contact information: a: Aerospace Manufacturing Research Centre (AMRC), Level 7, Tower Block, Faculty of Engineering, Universiti Putra Malaysia, 43400 Serdang, Selangor, Malaysia; b: Laboratory of Biocomposite Technology, Institute of Tropical Forestry and Forest Products (INTROP), Universiti Putra Malaysia, 43400 Serdang, Selangor, Malaysia;

*Corresponding author: n.razali_99@yahoo.com, thariq@upm.edu.my

\section{INTRODUCTION}

Composite materials are becoming more widely accepted and implemented in industry. There are core materials, prepegs, glass reinforcements, polyester/vinylsester resin, thermoset, etc., that have been used widely in automotive applications, machineries, aerospace applications, marine products, and others. Over the last decade, natural fibre reinforced polymer composites have been embraced by the European automobile manufacturers, especially in the manufacturing of door panels, seatback, package trays, dashboards, and trunk liners. Currently, the use of natural fibres has become wider and it has potential to replace synthetic fibre in most applications. In certain applications, impact damage may occur to the structure of the composites. It is important to study impact damage, since it may lead to catastropic failure to the structure.

Impact damage in composite structures is usually a result of the development of different failure modes induced in the zone surrounding the impact point. Impact events can be categorized in terms of four velocity ranges: low, high, ballistic, and hypervelocity (Santulli 2007). Low Velocity Impact (LVI) is normally defined by impact velocities less than $20 \mathrm{~m} / \mathrm{s}$. However, some consider impact velocities up to $40 \mathrm{~m} / \mathrm{s}$ to be categorized as 
LVI. LVI represents damage levels associated with situations such as the dropping of a hand tool during maintenance work $(<31 \mathrm{~m} / \mathrm{s})$ and other aircraft maintenance activities. Meanwhile, high velocity impacts (HVI) are associated with situations such as a bird colliding with an aircraft $(31 \mathrm{~m} / \mathrm{s}$ to $240 \mathrm{~m} / \mathrm{s})$. For impacts resulting from a projectile fired from a gun $(>240 \mathrm{~m} / \mathrm{s})$, the term "ballistic impact" is used. Finally, impacts of orbital debris roving in outer-space at velocities up to $15,000 \mathrm{~m} / \mathrm{s}$ are considered hypervelocity impact events. Because impacts can cause severe reductions in the stiffness and strength of composite structures, it is necessary to investigate the stiffness and strength of the material after an impact event.

Since the early 1970s, researchers have been using fiber and matrix toughening, interface toughening, through-thickness reinforcement, and hybridizing techniques to improve the impact properties of graphite composites. For high-performance materials, the choice of fibers can either be carbon or aramid-polyamides, such as Kevlar. These materials are very strong and are highly heat-resistant; therefore, these materials can be used in extreme aircraft applications such as the Euro Fighter 2000. A disadvantage of these materials is that they tend to be very expensive. There is a growing need for composite materials for use in military and civil applications, and there is a global search for materials with desirable structural characteristics that also maintain good penetration resistance and greater strength during impact events.

In the past, composites constituting the main material in structural applications were made from unidirectional (UD) layers. With UD layers, the majority of the fibers run only in one direction. The remaining small numbers of fibers running in the perpendicular directions are predominantly used to hold the primary fibers in position. This type of composite is not the best material for various applications due to a low transverse tensile strength. The most effective method of improving the impact behavior of composites is to introduce woven-fabric (WF) laminates, which is effective because WF has a much higher transverse tensile strength compared with the unidirectional composite. Although such fabrics are not commonly used in aerospace structures, the material is a competitive alternative to unidirectional composites in terms of impact resistance.

In recent years, there has been substantial interest in the application of natural fibers as reinforcements of polymer matrices due to ecological issues pertaining to climate change, greenhouse gases, etc. Natural fibers could be suitable replacements for synthetic fibers or glass fibers; their advantages in terms of environmental cost are high relative to their chemical and physical properties because natural fibre is much easier to find and produce. To reduce the dependence on petroleum-based products, it is necessary to explore environmentally friendly, sustainable materials to replace existing synthetic fibers.

There are various types of bio-composites; presently, the use of natural fiber as reinforcement is the most practical because of the relatively low price of biodegradable polymers. To produce more sustainable materials and reduce the carbon footprint during production and end-use while retaining sufficient mechanical resistance and impact performance, glass/plant fiber hybrid laminates have been considered (La Rosa et al. 2013). In a recent study on hybrid composites containing different amounts of glass and flax fibers, there was remarkable bridging between flax fibers, flax yarn, carbon fibers, and glass fibers with a positive effect on interlaminar shear strength and interlaminar fracture toughness (Zhang et al. 2013). The behavior of hybrid composites is a weighted sum of the individual components, in which there is a more favorable balance between 
the innate advantages and disadvantages. The advantages of one type of fiber could complement what is lacking in the others.

Natural fibers have many advantages over synthetic ones including limited harm to the environment, enhanced energy recovery and biodegradability, low density, high toughness, adequate specific strength, reduced dermal and respiratory irritation, low cost, renewability, and low energy input requirements for manufacture. Another major advantage is that they can be easily disposed of at the end of their life cycle by composting or by recovery of the calorific value in a furnace, which is not possible with glass fibers (Zhou et al. 2010; Sathish et al. 2012).

Despite their advantages, natural fibres also have disadvantages. The major disadvantages of the natural fibres in composites are the poor compatibility between fiber and many plastic matrix polymers and the relatively high moisture absorption (Naveen et al. 2016). Their high moisture absorption sensitivity can cause chemical degradation of the structure of the fibers, as well as dimensional variations of fibers, which leads to weak fiber-matrix interfacial adhesion (Ma et al. 2017). Other than that, natural fibers also have quality variations, low thermal stability, and poor compatibility with the hydrophobic polymer matrix (Ramesh Kumar and Mohanraj 2017).

Polyolefin thermoplastics such as polypropylene and polyethylene have been utilized as the matrix in bio-composites due to the limited development of biodegradable polymers, particularly for structural applications. The matrix in fiber-reinforced composite holds fibers together, transfers applied loads to those fibers, and protects them from mechanical damage and other environmental factors.

The properties of natural composites depend on the matrix, fibers, and interfacial bonding (Moigne et al. 2011). The adhesion between the reinforcing fibers and the matrix in composite materials is important for the final mechanical and physical properties of the material. Different types of bio-based fibers have different mechanical properties. Table 1 shows the mechanical properties of different bio-fibers.

Table 1. Mechanical Properties of Different Bio-Fibers

\begin{tabular}{|l|c|c|c|c|c|}
\hline \multicolumn{1}{|c|}{ Material } & $\begin{array}{c}\text { Density } \\
\left(\mathbf{g} / \mathbf{c m}^{\mathbf{3}}\right)\end{array}$ & $\begin{array}{c}\text { Tensile } \\
\text { Strength (MPa) }\end{array}$ & $\begin{array}{c}\text { Young's } \\
\text { Modulus (GPa) }\end{array}$ & $\begin{array}{c}\text { Elongation } \\
\text { at Break (\%) }\end{array}$ & References \\
\hline Abaca & 1.5 & 400 & 12 & $3-10$ & (Sanjay et al. 2015) \\
\hline Bamboo & 0.91 & 504 & 10.1 & 2 & (Sudarisman et al. 2015) \\
\hline Banana & 1.35 & $529-914$ & $27-32$ & 5.9 & (Sanjay et al. 2015) \\
\hline Coconut & 1.2 & $150-180$ & $4-6$ & $20-40$ & (Roy et al. 2014) \\
\hline Coir & 1.2 & 44 & 2.0 & $15-25$ & (Yusoff et al. 2016) \\
\hline cotton & 1.51 & 400 & 12 & $3-10$ & (Kristaiah et al. 2014) \\
\hline Curaua & 1.4 & $500-1150$ & 11.8 & $3.7-4.3$ & (Sanjay et al. 2015) \\
\hline Flax & 1.4 & $800-1500$ & 27.6 & $1.2-1.6$ & (Kristaiah et al. 2014) \\
\hline Hemp & 1.48 & $350-800$ & $30-60$ & $1.6-4.0$ & (Roy et al. 2014) \\
\hline Jute & 1.3 & $300-700$ & $20-50$ & $1.2-3.0$ & (Roy et al. 2014) \\
\hline Kenaf & 1.18 & $280-370$ & $22-28$ & $1.7-2.1$ & (Yusoff et al. 2016) \\
\hline Spiker Sile & 1.3 & $1300-2000$ & 30 & $28-30$ & (Roy et al. 2014) \\
\hline Sugar palm & 1.29 & 190.29 & 3.69 & - & (Bachtiar et al. 2010) \\
\hline Pineapple & 1.44 & $413-1627$ & $60-82$ & 14.5 & (Sanjay et al. 2015) \\
\hline Ramie & 1.5 & 500 & 44 & 2 & (Kristaiah et al. 2014) \\
\hline Sisal & 1.5 & $300-500$ & $10-30$ & $2-5$ & (Roy et al. 2014) \\
\hline Glass Fiber & 2.5 & $1200-1800$ & 72 & 2.5 & (Roy et al. 2014) \\
\hline Carbon Fiber & 1.4 & 4000 & 235 & 2 & (Roy et al. 2014) \\
\hline Kevlar 49 & 1.44 & $3600-4100$ & 130 & 2.8 & (Roy et al. 2014) \\
\hline
\end{tabular}


The term "biocomposite" is employed when natural fibers are used as an environmentally friendly alternative to composites containing traditional fibers. To some extent, however, biocomposites still depend on oil and can cause waste problems due to the use of non-degradable polymer matrices. The technique used to manufacture biocomposites are based on existing techniques such as press moulding, hand layup, pultrusion, injection moulding, filament winding, and resin transfer moulding, etc. Figure 1 shows the global composites materials used in current industries in various application.

\section{Global composites applications}

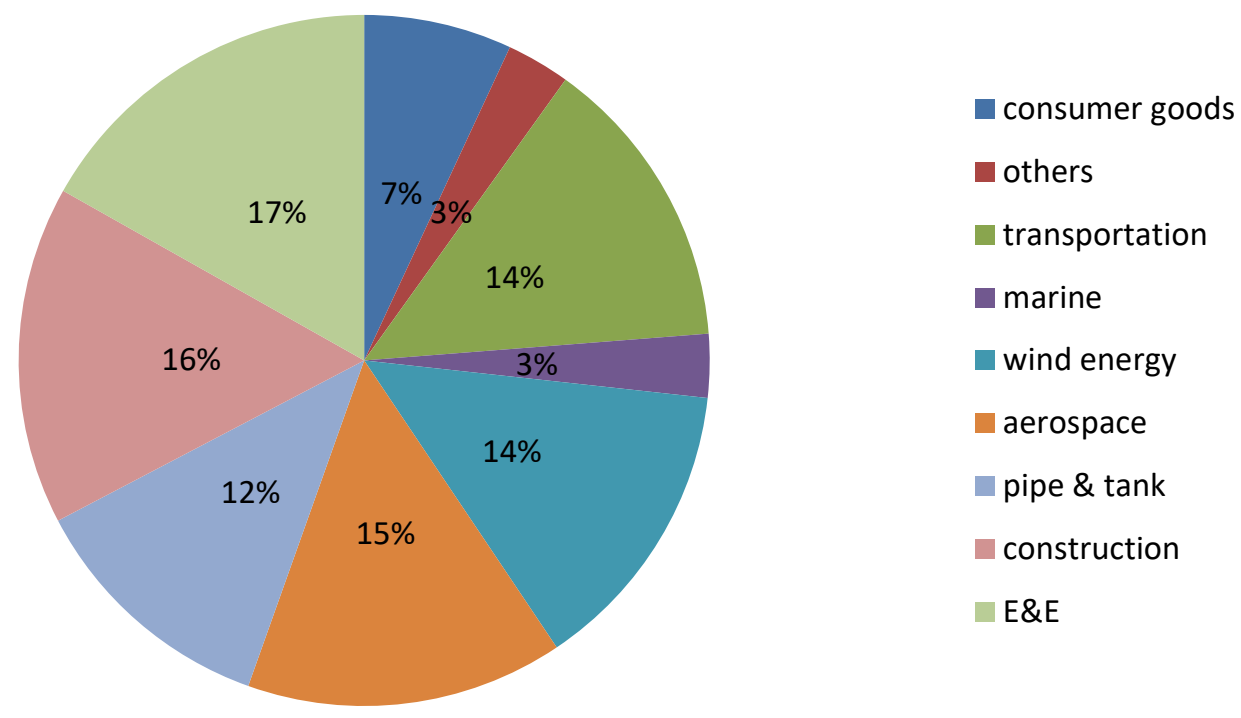

Fig. 1. Global composite application in recently (Source: Development in Biocomposites articles)

Fibers may possess high strength and stiffness, but they can be difficult to use in load-bearing applications because of their fibrous structure. Composites based on natural fibers are lightweight, with a high strength-to-weight ratio and good stiffness. Unfortunately, there can be problems with the technical properties of reinforced materials. Moisture absorption is generally high, and impact strength is relatively low. The price difference between bio-composites and synthetic plastics is expected to narrow as a result of continued breakthroughs in production and processing technology, increases in base crude oil, close substitute energy prices, and government regulations favouring the greater use of renewable energy and reclaimed waste materials (Lee et al. 2003; Mohanty et al. 2005).

Manufacturing new composites can incur lots of cost. If the composites can continue to be used over long periods of time, that would be an advantageous situation compared to manufacturing new composite material. In order to maintain the use of the composites, much research has been conducted to see the effect of time and defect to the composites structures. The wide involvement of composites in the production of important structures such as automotive, aerospace machineries, etc., demands that adequate and periodic testing be carried out on them before and during the service to ensure that the materials did not deviate from the original design (Gbenga 2016). Impact damage testing and incipient thermal damage testing need to be conducted on composites before they can be used in order to know the strength of the materials. It is also important 
to know the properties of the material. During service, to maintain the materials, nondestructive testing can be used to detect damage on or inside the composites.

\section{Impact Damage}

Numerous studies have reported on the excellent impact response of fibers, and extensive experimental data has been compiled. Atas and Sayman (2008) investigated the impact response of woven fabric composite plates made of E-glass. To fabricate the composite panel, two different types of resin and hardener were chosen: type SC-15A resin and SC-15B hardener. The fabricated composite laminate had four layers, with the dimensions of the test plates being $100 \mathrm{~mm} \times 100 \mathrm{~mm} \times 2.2 \mathrm{~mm}$. The composite was precured at $60{ }^{\circ} \mathrm{C}$ for $2 \mathrm{~h}$, followed with a curing at $93{ }^{\circ} \mathrm{C}$ for $4 \mathrm{~h}$ at a constant pressure of $0.35 \mathrm{MPa}$. An instrumented drop test machine equipped with a $12.5 \mathrm{~mm}$ impactor and a $22.24 \mathrm{kN}$ load cell were used for the impact test. The impact energy varied between $4 \mathrm{~J}$ and $45 \mathrm{~J}$. As the impact energy increased, the impact damage area increased proportionally. The type of damage in the test specimens included fiber breakage, fiber pullout, and a visible indentation area, which was detected at the impact energy of $38 \mathrm{~J}$. The study concluded that the radius of the impactor nose to plate thickness ratio played an important role in determining the penetration threshold, penetration range, and perforation threshold of the impacted specimen. However, attention was paid in the study only to woven fabric composite plates made of E-glass. Therefore, there is a critical need to examine the impact response of bio-composites and compare the differences between the results and the literature concerning woven fabric composite plates made of fiberglass and natural fibers.

Kim et al. (2005) studied damage in graphite/epoxy (Gr/Ep) composite laminate by using signals recorded in polyvinylidene fluoride (PVDF) and lead zirconate titanate (PZT) film sensors. The PVDF thin film sensors used in the work were DT1-028 and measured $15 \mathrm{~mm}$ long, $10 \mathrm{~mm}$ wide, and $28 \mu \mathrm{m}$ thick. The PZT sensors that were used were C-82 and measured $15 \mathrm{~mm}$ long, $10 \mathrm{~mm}$ wide, and $461 \mu \mathrm{m}$ thick. Sixteen impact tests with four different impact masses and five different impact heights were conducted. The impact energy was calculated by multiplying the weight and height of the impactor, and the laminate panels were impacted normal to the surface using energies for the instrumented impactor ranging from $0.123 \mathrm{~J}$ to $10.319 \mathrm{~J}$. The sensor signals were recorded using a digital memory oscilloscope (Tektronics, TDS340). It was experimentally verified that damage caused by low velocity impact is not easily detected by the naked eye. A drop weight was used to create the impact damage; the impact energy was calculated from the weight and drop height of the impactor. The authors concluded that both types of piezo-sensors were very sensitive to the vibrations and stress waves generated by low-velocity impact events, which proved useful in the prediction of impact damages. Because the described study has heightened the need to use sensor electrical signals for damage detection, ongoing work will seek to characterize impacts on the basis of response measurements from permanently installed sensors. The type of sensors that were chosen for the current research were disc-shaped SONOX ®P5 PZT sensors measuring $10 \mathrm{~mm}$ in diameter and having a thickness of $1 \mathrm{~mm}$. Disc-shaped PZT sensors are ideal for converting a variety of physical quantities into electrical signals for low and high velocity related applications. Table 2 illustrates the sensors that have been used for detecting damage in previous studies of various composites. 
Table 2. Sensors Used for Detecting Damage in Previous Papers

\begin{tabular}{|c|c|c|c|c|}
\hline Composites & Sensor & Application & Year & Reference \\
\hline $\begin{array}{c}\text { Kevlar/epoxy skins and NOMEX } \\
\text { core }\end{array}$ & Fiber-optic & Aircraft leading edge & 1992 & $\begin{array}{l}\text { LeBlanc et } \\
\text { al. }\end{array}$ \\
\hline $\begin{array}{l}\text { Carbon fiber reinforced } \\
\text { composite }\end{array}$ & $\begin{array}{l}\text { Intensity-modulated } \\
\text { sensor based on the } \\
\text { microbending } \\
\text { concept }\end{array}$ & - & 2000 & $\begin{array}{l}\text { Rippert et } \\
\text { al. }\end{array}$ \\
\hline $\begin{array}{l}\text { Advanced composite materials } \\
\text { (thermoplastic-based laminates of } \\
\text { alternating layers of Al \& glass- } \\
\text { fiber/PP (GF/PP) prepregs) and } \\
\text { fiber/metal laminates(FMLs) (Al } \\
\text { alloy sheet and glass-fiber } \\
\text { reinforced PP prepreg) }\end{array}$ & $\begin{array}{l}\text { Fiber Bragg grating } \\
\text { (FBG) sensor }\end{array}$ & Tensile test & 2001 & Kuang et al. \\
\hline $\begin{array}{c}0^{0} \text { ply of a CFRP cross-ply } \\
\text { laminate }\end{array}$ & Small-diameter FBG & Various Tensile test & 2002 & $\begin{array}{l}\text { Okabe et } \\
\text { al. }\end{array}$ \\
\hline Epoxy matrix and glass fiber & $\begin{array}{c}\text { piezoelectric smart } \\
\text { materials }\end{array}$ & $\begin{array}{c}\text { Crack damage } \\
\text { detection }\end{array}$ & 2002 & $\begin{array}{l}\text { Yan and } \\
\text { Yam }\end{array}$ \\
\hline CFRP laminates & $\begin{array}{l}\text { Extrinsic Fabry-Perot } \\
\text { interferometer (EFPI) } \\
\text { and FBG }\end{array}$ & $\begin{array}{l}\text { Monitoring cure } \\
\text { process }\end{array}$ & 2003 & $\begin{array}{l}\text { Leng and } \\
\text { Asundi }\end{array}$ \\
\hline $\begin{array}{l}\text { Cross-ply glass fiber/polyester } \\
\text { laminate }\end{array}$ & $\begin{array}{l}\text { FBG and a Fabry- } \\
\text { Perot interferometer }\end{array}$ & Tensile loading & 2004 & $\begin{array}{l}\text { DeOliveira } \\
\text { et al. }\end{array}$ \\
\hline CFRP cross-ply laminate & FBG & $\begin{array}{c}\text { Quasi-static tensile } \\
\text { test }\end{array}$ & 2005 & $\begin{array}{l}\text { Yashiro } \\
\text { et al. }\end{array}$ \\
\hline CFRP cross-ply laminates & FBG & $\begin{array}{l}\text { Detect interlaminar } \\
\text { delamination using } \\
\text { Lamb wave sensing }\end{array}$ & 2005 & $\begin{array}{l}\text { Takeda } \\
\text { et al. }\end{array}$ \\
\hline $\begin{array}{l}\text { Hat-shaped stringer reinforced by } \\
\text { stitched fiber. The skin part was a } \\
\text { conventional prepreg lay-up. }\end{array}$ & FBG & $\begin{array}{l}\text { Drop-weight impact } \\
\text { tests and fatigue } \\
\text { tests }\end{array}$ & 2007 & $\begin{array}{l}\text { Takeda } \\
\text { et al. }\end{array}$ \\
\hline Carbon fibre/epoxy laminate & $\begin{array}{l}\text { FBG and Fabry- } \\
\text { Perot interferometer }\end{array}$ & $\begin{array}{l}\text { Strain and acoustic } \\
\text { emission sensing }\end{array}$ & 2008 & $\begin{array}{l}\text { DeOliveira } \\
\text { et al. }\end{array}$ \\
\hline Carbon/epoxy beams & $\begin{array}{l}\text { EFPI strain sensors } \\
\text { (SSs) }\end{array}$ & Tensile test & 2009 & $\begin{array}{l}\text { Zhou and } \\
\text { Sim }\end{array}$ \\
\hline CFRP & $\begin{array}{l}\text { sparse array of FBG } \\
\text { sensors. }\end{array}$ & $\begin{array}{l}\text { Localization of } \\
\text { impacts }\end{array}$ & 2011 & Kirkby et al. \\
\hline Carbon composite & $\begin{array}{c}\text { Polarization } \\
\text { Maintaining Photonic } \\
\text { Crystal Fiber } \\
\text { (PMPCF) }\end{array}$ & Strain measurement & 2011 & $\begin{array}{l}\text { Thakur } \\
\text { et al. }\end{array}$ \\
\hline CFRP prepreg & PZT sensors & $\begin{array}{c}\text { To perform } \\
\text { damaging impact } \\
\text { tests }\end{array}$ & 2011 & Sultan et al. \\
\hline $\begin{array}{l}\text { Glass fiber fabrics /polyester } \\
\text { resin }\end{array}$ & $\begin{array}{l}\text { photonic crystal fiber } \\
\text { (PCF) sensors }\end{array}$ & $\begin{array}{l}\text { Measurements of } \\
\text { local and average } \\
\text { strain and temp. }\end{array}$ & 2012 & Rajan et al. \\
\hline CFRP laminate & FBG sensor & $\begin{array}{c}\text { Damage detection in } \\
\text { a holed CFRP under } \\
\text { static and cyclic } \\
\text { loading }\end{array}$ & 2012 & $\begin{array}{l}\text { Okabe and } \\
\text { Yashiro }\end{array}$ \\
\hline CFRP & FBG sensor & Strain & 2012 & $\begin{array}{l}\text { Frieden } \\
\text { et al. }\end{array}$ \\
\hline $\begin{array}{l}\text { Glass/epoxy prepreg and } \\
\text { carbon/epoxy prepreg }\end{array}$ & FBG sensor & Strain & 2013 & $\begin{array}{l}\text { Pereira } \\
\text { et al. }\end{array}$ \\
\hline
\end{tabular}


Pereira et al. (2013) characterized the combined behavior of the sensors and the host material, then defined the procedure to obtain a more accurate strain for the newly chosen material. The work discussed in their paper was a continuation of a novel method to improve the reliability and accuracy of the strain measurements on unidirectional composites using embedded FBG sensors. To compare the strain transfer between the sensor and the host material, two materials with different tensile moduli (glass fiber and carbon fiber) were used.

Okabe et al. (2012) discussed the damage detection in a holed CFRP laminate under static and cyclic loading using an embedded fiber Bragg grating (FGB) sensor. The change in the spectrum shape was measured in order to detect the damage extension in the laminate. These results were compared with results obtained by numerical simulation. The shape of the reflection spectrum did not change during the cyclic load test, but it did change with an increase of strain in the static load test, due to the existing damage around the hole. Based on these results, fatigue damage around a hole in a composite laminate may not be detected with an FBG sensor due to debondings observed between the optical fibers and matrix during the cyclic load test.

Rogge and Leckey(2013) characterized impact damage in composite laminates using guided wavefield imaging and local wavenumber domain analysis. Conventional ultrasonic scanning techniques effectively characterize the size and depth of delaminations, but they require physical contact with the structure and considerable setup time. A local Fourier domain analysis method was presented for processing guided wavefield data to estimate spatially dependent wavenumber values, which can be used to determine delamination depth. This technique was applied to simulate a wavefield, and the results were analyzed to determine limitations of the technique with regard to determining defect size and depth. Guidelines for application of the technique were developed based on the simulation results. Rogge and Leckey (2013) then obtained experimental wavefield data in quasi-isotropic CFRP laminates with impact damage. The recorded wavefields were analyzed, and the wavenumber was measured to an accuracy of up to $8.5 \%$ in the region of shallow delaminations. These results showed the promise of local wavenumber domain analysis to characterize the depth of delamination damage in composite laminates. The technique could be applied in automated vehicle health assurance systems, with potential for high detection rates. This method would greatly reduced operator effort and setup time.

Sarasini et al. (2016) conducted an experiment which included four-point bending, falling weight impact test at various energy levels (5 to $30 \mathrm{~J}$ ) with determination of the barely visible impact damage (BVID), and post impact flexural tests for carbon/flax hybrid composites. As the test was conducted, carbon/flax/carbon proved slightly superior to flax/carbon/flax combination as for flexural performance, although the presence of flax laminates on the outside guaranteed a higher impact damage tolerance, acting as hindrance to crack propagation in the laminates. The specimens also were monitored by Digital Image Correlation (DIC) that allowed preminary identification of peculiar failure modes of the hybrid laminates.

Petrucci et al. (2015) conducted an experimental study of impact and post-impact damage characterization of hybrid composite laminates based on basalt fibers in combination with flax, hemp, and glass fibers manufactured by vacuum infusion. The impact and flexural post-impact behavior of ternary hybrid composites based on epoxy resin reinforced with different types of fibres, basalt $(B)$, flax $(\mathrm{F})$, hemp $(\mathrm{H})$, and glass (G) in textile form, namely FHB, GHB, and GFB, were investigated. The reinforcement 
volume employed was in the order of $21 \%$ to $23 \%$ throughout. Laminates based exclusively on basalt, hemp, and flax fibers were also fabricated for comparison. Hybrid laminates showed an intermediate performance between basalt fiber reinforced laminates on the high side, and flax and hemp fiber reinforced laminates on the low side. As for impact performance, GHB appears to be the worst performing hybrid laminate, and FHB performs slightly better than GFB. Generally, an increased rigidity can be attributed to all hybrids with respect to flax and hemp fiber composites. The morphological study of fracture by SEM indicated the variability of mode of fracture of flax and hemp fiber laminates and of the hybrid configuration (FHB) containing both of them. Acoustic emission monitoring during post-impact flexural tests confirmed the tendency to delamination of FHB hybrids, while they were able to better withstand impact damage than the other hybrids. Table 3, showing data from Grytten (2008), provides very useful information about the different velocity regimes and their corresponding application and test methods.

Table 3. Velocity Regimes and Corresponding Applications for Test Methods (Grytten 2008)

\begin{tabular}{|c|c|c|c|}
\hline $\begin{array}{l}\text { Velocity } \\
\text { Regime }\end{array}$ & $\begin{array}{c}\text { Impact Test } \\
\text { Equipment }\end{array}$ & Material Test Method & Typical Applications \\
\hline $\begin{array}{l}\text { Low velocity } \\
0-50 \mathrm{~m} / \mathrm{s}\end{array}$ & $\begin{array}{l}\text { - Drop hammer } \\
\text { - Pneumatic } \\
\text { accelerator }\end{array}$ & $\begin{array}{l}\text { Quasi-static testing } \\
\text { machines: } \\
\text { - hydraulic } \\
\text { - servo-hydraulic } \\
\text { - screw-driven }\end{array}$ & $\begin{array}{l}\text { - Dropped objects } \\
\text { - Vehicle impact/ship } \\
\text { collision } \\
\text { - Crashworthiness of } \\
\text { - Containers for hazardous } \\
\text { materials }\end{array}$ \\
\hline $\begin{array}{l}\text { Sub-ordnance } \\
50-500 \mathrm{~m} / \mathrm{s}\end{array}$ & $\begin{array}{l}\text { - Compressed air } \\
\text { gun } \\
\text { - Gas gun }\end{array}$ & $\begin{array}{l}\text { - Pneumatic } \\
\text { - Hydraulic } \\
\text { - Taylor impact tests } \\
\text { - Split Hopkinson } \\
\text { - Pressure bar } \\
\text { (SHPB)or Tension } \\
\text { bar(SHTB) }\end{array}$ & $\begin{array}{l}\text { - Design of nuclear } \\
\text { containment } \\
\text { - Free-falling bombs \& } \\
\text { missiles } \\
\text { - Fragments due to } \\
\text { accidental explosions }\end{array}$ \\
\hline $\begin{array}{l}\text { Ordnance } \\
500-1300\end{array}$ & $\begin{array}{l}\text { - Compressed air } \\
\text { gun gas gun }\end{array}$ & $\begin{array}{l}\text { - Taylor tests } \\
\text { - SHPB/SHTB }\end{array}$ & - Military \\
\hline $\begin{array}{l}\text { Ultra-ordnance } \\
1300-3000 \mathrm{~m} / \mathrm{s}\end{array}$ & $\begin{array}{l}\text { - Powder gun } \\
\text { - Two-stage light } \\
\text { gas gun }\end{array}$ & - Taylor impact test & - Military \\
\hline $\begin{array}{l}\text { Hypervelocity } \\
>3000 \mathrm{~m} / \mathrm{s}\end{array}$ & $\begin{array}{l}\text { Two-stage light } \\
\text { gas gun }\end{array}$ & - Taylor impact test & $\begin{array}{l}\text { - Space vessels } \\
\text { - Exposed to meteoroid } \\
\text { impact\& space debris }\end{array}$ \\
\hline
\end{tabular}

Schrauwen and Peijs (2002) performed an experimental investigation on the influence of the matrix ductility and fiber architecture by implementing repeated impact tests on laminated fiberglass composites. To investigate the penetration energy and development of damage in the composite material, a drop test rig was used while the force was measured using a piezoelectric force transducer. The test specimens for this research were fabricated using a hand lay-up with a total of 16 specimens with four different resin and reinforcement combinations. Throughout the testing, the mass of the impactor and the drop height remained at $2.85 \mathrm{~kg}$ and $2 \mathrm{~m}$, respectively.

It was evident that numerous specimens were required for validating an impact study in order to assure that different impact regimes were covered and that repeatability 
of the impacts could be verified. The impacted specimens were later C-scanned and visually examined to determine the extent of the delaminations that occurred from the impact. This study showed that the penetration energy is highly dependent on the type of reinforcements, while the development of damage during repeated impact events is influenced by both the type of resin and the architecture of the fibers. Table 4 shows the fabrication method, matrix polymer used, and type of impact damage on the composite that was recorded by the previous researchers.

Table 4. Impact Studies by Previous Researchers

\begin{tabular}{|c|c|c|c|c|c|c|}
\hline Composite & Matrix Polymer & $\begin{array}{l}\text { Fabrication } \\
\text { Method }\end{array}$ & Thickness & Impact & Year & Reference \\
\hline CFRP & Prepeg & & $4 \mathrm{~mm}$ & Steel ball drop & 2014 & Fu et al. \\
\hline $\begin{array}{l}\text { Novel based bio- } \\
\text { composite } \\
\text { reinforced; } \\
\text { unidirectional high } \\
\text { strength Mg-alloy } \\
\text { wires }\end{array}$ & $\begin{array}{l}\text { Poly-lactic acid } \\
\text { (PLA) }\end{array}$ & $\begin{array}{l}\text { Hot } \\
\text { compressing } \\
\text { process } \\
\text { (lamina } \\
\text { stacked } \\
\text { method) }\end{array}$ & $2 \mathrm{~mm}$ & $\begin{array}{l}\text { ZBC impact } \\
\text { testing }\end{array}$ & 2014 & Li et al. \\
\hline CFRP & Prepeg & & & $\begin{array}{l}\text { Instrumented } \\
\text { hammer (non- } \\
\text { destructive) }\end{array}$ & 2012 & Frieden et al. \\
\hline $\begin{array}{l}\text { CFRP } \\
\text { GFRP }\end{array}$ & Polyimide & & $0.76 \mathrm{~mm}$ & $\begin{array}{l}\text { Tensile } \\
\text { (stress/strain) } \\
\text { Fatigue test }\end{array}$ & 2012 & $\begin{array}{l}\text { Okabe and } \\
\text { Yashiro }\end{array}$ \\
\hline Carbon/epoxy UD & $\begin{array}{l}\text { Prepeg } \\
\text { LTM45-EL }\end{array}$ & $\begin{array}{l}\text { Autoclave } \\
\text { cured }\end{array}$ & $4 \mathrm{~mm}$ & $\begin{array}{l}\text { Cantilever, } \\
\text { flexure in three- } \\
\text { point bending, } \\
\text { ILS in short beam } \\
\text { shear }\end{array}$ & 2009 & Zhou and Sim \\
\hline $\begin{array}{l}\text { Hybrid palms- } \\
\text { kevlar }\end{array}$ & Araldite & $\begin{array}{l}\text { Hand } \\
\text { molding }\end{array}$ & & Charpy impact & 2012 & $\begin{array}{l}\text { Al-Mosawi et } \\
\text { al. }\end{array}$ \\
\hline Hermes flax fibers & 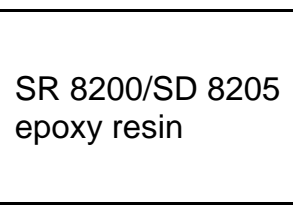 & $\begin{array}{l}\text { Hand lay-up } \\
\text { in hot press } \\
\text { machine }\end{array}$ & $\begin{array}{c}2.85(0.07) \\
\mathrm{mm}\end{array}$ & $\begin{array}{l}\text { Falling weight } \\
\text { impact;Compressi } \\
\text { on } \\
\text { Three point } \\
\text { bending }\end{array}$ & 2015 & Liang et al. \\
\hline $\begin{array}{l}\text { Hybrid basalt, flax, } \\
\text { hemp, glass }\end{array}$ & Epoxy resin & $\begin{array}{l}\text { Vacuum } \\
\text { infusion }\end{array}$ & $2-3.9 \mathrm{~mm}$ & $\begin{array}{l}\text { Falling weight } \\
\text { impact }\end{array}$ & 2015 & Petrucci et al. \\
\hline Glass fiber & $\begin{array}{l}\text { Epoxy matrix } \\
\text { Epoxy modified tri- } \\
\text { block copolymer } \\
\text { (nanostrength) } \\
\text { matrix }\end{array}$ & $\begin{array}{l}\text { Compressio } \\
\mathrm{n} \text { moulding }\end{array}$ & $1 \mathrm{~mm}$ & Drop weight & 2015 & Matadi et al. \\
\hline E-glass /basalt & $\begin{array}{l}\text { Bi-component } \\
\text { epoxy resin }\end{array}$ & $\begin{array}{l}\text { Resin } \\
\text { transfer } \\
\text { moulding }\end{array}$ & $\begin{array}{c}3.5 \pm 0.15 \\
\mathrm{~mm}\end{array}$ & $\begin{array}{l}\text { Falling dart impact } \\
\text { testing }\end{array}$ & 2013 & Sarasini et al. \\
\hline CFRP & Prepeg MTM resin & $\begin{array}{l}\text { Hand lay up } \\
\text { Vacuum } \\
\text { bagging } \\
\text { autoclave }\end{array}$ & $\begin{array}{l}3.5,3.8 \\
4.1 \mathrm{~mm}\end{array}$ & Drop test rig & 2012 & Sultan et al. \\
\hline GFRP & Epoxy resin & Hand lay up & $\begin{array}{c}6,8,10,12 \\
\mathrm{~mm}\end{array}$ & $\begin{array}{l}\text { Single Stage Gas } \\
\text { Gun }\end{array}$ & $\begin{array}{l}2014 \\
\text { (a) }\end{array}$ & Razali et al. \\
\hline GFRP & Epoxy resin & Hand lay up & $5-8 \mathrm{~mm}$ & $\begin{array}{l}\text { Drop Weight } \\
\text { impact test }\end{array}$ & 2014 & $\begin{array}{l}\text { Razali and } \\
\text { Sultan }\end{array}$ \\
\hline
\end{tabular}


The development of damage discussed in this paper is mainly a consequence of the type of reinforcement, type of resin, and architecture of the fiber. These same factors may also apply to bio-composites, which were employed in the current work. It would also be wise to examine the failure modes and damage progressions with closer scrutiny by using other related NDE techniques apart from what has been discussed in this review.

\section{Incipient Thermal Damage (ITD)}

Heating events such as fire, exhaust wash, or engine overheating during the service life of composite structures and materials could cause resin degradation, further causing these materials to experience a significant reduction in room-temperature mechanical strength properties (Matzkanin and Hansen 1999). Below a certain exposure threshold, these composites can appear undamaged to visual inspection and conventional non-destructive testing techniques, but they may have lost a significant percentage $(60 \%)$ of their original strength (Pereira 2013). This type of damage, known as incipient thermal damage (ITD), cannot be detected even by state-of-the-art non-destructive testing (NDT) or non-destructive evaluation (NDE) systems.

To detect the ITD in composite materials, Howie et. al. (2012) proposed the use of fluorescent thermal damage probes. The fluorescent thermal damage probes were incorporated into the matrix of the composite during material fabrication. The probes exhibit an irreversible fluorescence emission colour shift or intensity change upon reaching an activation temperature. Illuminating the composite materials with light of suitable excitation wavelength can hence show fluorescent light at regions with potential ITD. The Fourier transform infrared spectroscopy (FTIR) method has also been adopted by the aviation industry ( $\mathrm{Fu}$ and $\mathrm{Li} 2014$ ) to identify composite structures that are in need of repair, using ITD. Another similar method, laser-induced fluorescence method (Fisher et al. 1997), was also proposed for the detection of ITD. Clearly, methods based on surface inspection can detect ITD only for a very thin ( $\mu \mathrm{m}$ range) layer of material, and their effective usage for predicting bulk mechanical properties is questionable. Unfortunately, cost-effective repair or the decision for part replacement can only be done based on a comprehensive understanding of the damage throughout the full thickness of the material. Currently, mechanics are forced to sand the top layer of material away before subsequent inspections can be done on the inner layers of material. Lindgren et al. (2006) proposed the use of sonic infrared method (also known as sonic IR) for detecting ITD through the thickness of composite materials. An ultrasonic horn was used for locally heating the composite with mild temperature elevation through thermo-elastic absorption, and an IR camera, placed at the other side of the materials, was used for measuring the volumetric heating of the sample due to the thermo-elastic dampening. Sathish et al. (2005) reported that the thermo-elastic absorption and dampening in composite materials were governed by Young's modulus, internal friction, specific heat at constant pressure, and the thermal conductivity of the materials. While heat exposure permanently changes the local values of these parameters, the sonic infrared imaging can register a different heat signature at locations with ITD. The accuracy and effectiveness of the sonic infrared method is dependent on the standoff distance of ultrasonic horn. In other words, designing fixtures with surface profile following capability for components and specimens to ensure a repeatable excitation at appropriate acoustic frequency is very challenging (Sathish et al. 2012). This limits its potential usage for point measurement to specific locations of interest only, and further hinders its acceptance by the industrial 
community. The shortcomings of the conventional methods are apparent, and effort must be applied to solve this problem.

A time history thermography method is proposed for this project as an advanced NDE tool to evaluate ITD. A suitable non-destructive heating aparatus will be used for specimen excitation as a localized surface heating source. An infrared (IR) camera is used to collect time histories of the localized surface heating. Full time history of the surface heating was used for the evaluation of ITD. ITD alters the thermal properties of a specimen at the surface and through the thickness, and it is expected that heat dissipation pattern of a specimen at region with ITD is different from an intact region, although thermal excitation is only performed at the surface of the specimen. This difference was registered by the IR camera, and a novel image processing method will be developed to highlight and evaluate the ITD. Compared with the sonic infrared method, this proposed method provides comparable sensitivity of ITD evaluation through the material thickness, without the need of a surface profile-following fixture. Numerical analysis is essential to minimizing the time and cost of fabrication. Testings of actual laminates are also proposed for this project based on the finite element method (FEM). Through reliable numerical simulations, further investigations and parametric studies on damaged laminates subjected to heat can be performed. In addition, material property degradation as a result of various temperature exposures as well as various modes of failure may also be investigated.

\section{Failure Modes of Composites}

Impact damage may lead to several types of failure. Some of the targets will be penetrated by the impactor and some of them only will receive minor damage at the surface area. In the case of damage, several failure modes must be occur such as delamination, matrix cracking, matrix breakage, fiber breakage, fiber pullout. The failure modes of the composites will be depends on the materials properties, matrix properties, impact velocity, projectile nose shape, and target geometry, etc. Delamination is a crack that occurs in the resin area between resin and fiber plies of different fibre orientation. Matrix failure is the first failures that occurs before the fiber failure. Matrix cracks occur due to property mismatching between the fibre and matrix, and are usually oriented in planes parallel to the fibre direction in unidirectional layers. Fibre failure generally occur after the matrix failure and delamination. It occurs due to highly stress impact and it may lead to catastrophic penetration modes (Razali et al. 2014b).

\section{APPLICATIONS}

\section{Composite Application in Aerospace}

In the aviation industry, the operating costs are extremely high, there is high competition, and, in most cases, the profit returned is small. Even though the composite would reduce weight and increase corrosion resistance, the acceptance of composite application in the aircraft structure has been slower than expected. The reasons for the reluctance of use are due to its high cost of certification and production costs for composite components (Harris et al. 2002). The cost of composites is the main hindrance to greater wider application (Freeman 1993).

Harris et al. (2002) noted that the cost of manufacturing and maintenance of composite structures must not be greater than that of aluminium alloy, but it needs to 
maintain the advantage of reducing weight. However, impact damage and the strength become hindrance factors. Other problems include poor reliability in estimating the development costs and inability to accurately predict structural failure.

The application of composite materials in large aircraft structures has increased over the past half-decade, but manufacturers found solutions to lower the cost of production of composite structures. The largest user of composite materials today is the transportation industry, which consumed 1.3 billion pounds of composites in 2000 (Mazumdar 2001). As an example, Airbus Industries has continued implementing composite structures into its new aircraft program. In the A380 structure, the amount of composite applications is approximately $16 \%$ of the total airframe weight. This is equivalent to the replacement of about $20 \%$ of conventional aluminium structure by composites. Before Airbus Industries started the innovation, most large commercial transport aircraft designs limited the use of composite materials to secondary structures such as ailerons, flaps, elevators, and rudders.

The Airbus A380 will employ carbon fiber reinforced plastic composite materials in the massive wing carry-through structure. Resin infusion is used to form the rear pressure bulkhead and several of the wing panels. Leading edges will be thermoplastic to obtain improved impact resistance. The upper fuselage skin panels will be manufactured from a hybrid metal and fiberglass laminate. Figure 2 illustrates the material used on the A380 as projected in the advanced development stage of the project. The carry through structure represents probably the largest, most complex, and most critical aerospace composite structure attempted in civil aircraft applications (Pora 2001).

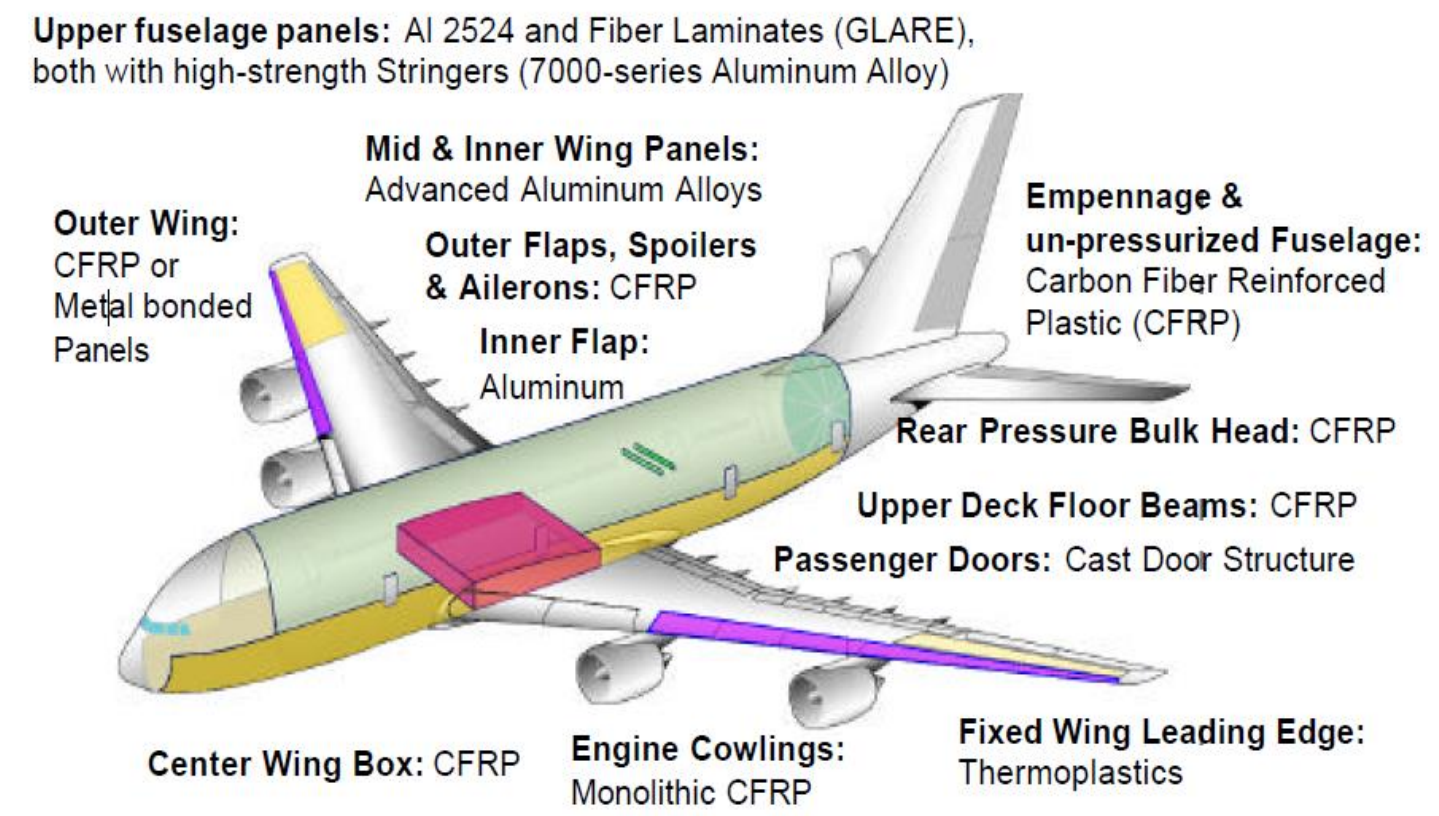

Lower Fuselage Panels: Laser-beam-welded Aluminum Alloys

Fig. 2. Advanced composites material selected for A380 (Source: Courtesy of Airbus Industries)

Due to unexpected runway debris, bird collision during flight, hand tools dropped during maintenance work, and other types of impact damage that may result in catastrophic failure, a few systems were created to detect the damage and monitor the structural health. Panopoulou et al. (2011) developed a new system for structural health 
monitoring of aerospace composite structures based on real-time dynamic measurements, to identify the condition of the structure. Long-gauge Fiber Bragg Grating (FBG) optical sensors were used to monitor the dynamic response of composite structures. The algorithms were developed to detect structural damage using dynamic response data that was collected. The data were analyzed in a variety of ways. By use of artificial neural networks it was possible to identify the state of damage and its exact location. Validation experiments were carried out initially on flat stiffened panels that were manufactured and tested in the laboratory and represented part of the normal aeronautical structures. As a second step, the space-oriented structure, which is a honeycomb composite plate, was improved and used as a base for the array of antenna placement. Figure 3 illustrate the process to manufacturing the honeycomb composites plate that is used in most structure application. Honeycomb are produced from an expansion process of plates that had been laser weld or adhesive bond strips to each other and form a block of sheets. These are later pulled apart to create expanded panel. The method is used not only because of their advantages in term of weight saving and structural performances, but also as an effective means to reduce cost.

The FBG sensor network integration, based on the advantages of multiplexing, was installed on both the structure and position of different excitation; boundary conditions were used. Analysis of the dynamic response operation identified both the damage and its position. The system was tested initially on a thin composite panel and was successfully validated on the honeycomb structure.

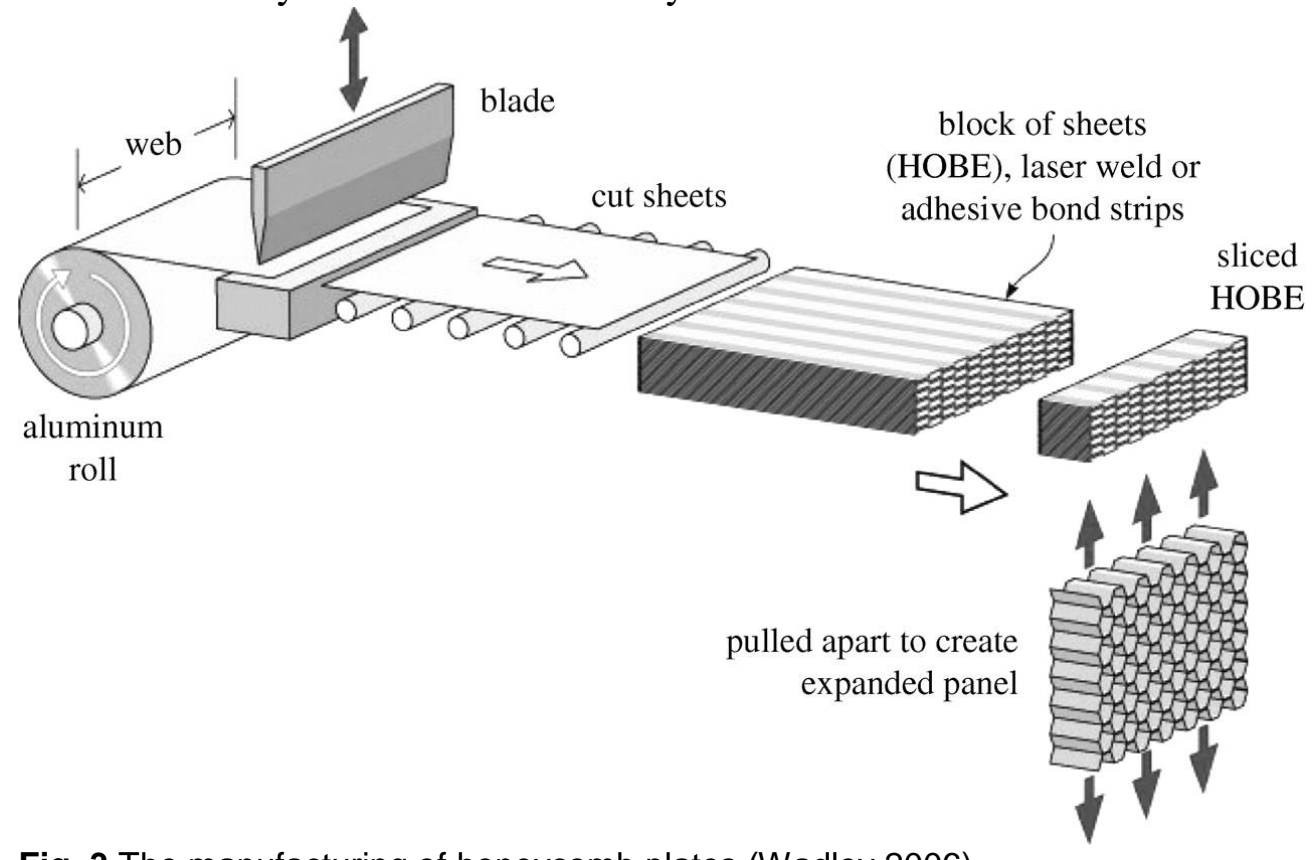

Fig. 3.The manufacturing of honeycomb plates (Wadley 2006)

Appleby-Thomas et al. (2015) had made an attempt to investigate the effect of a more complex geometric structure comprising two dimensional flat and peaked-nose structures on composite systems. A series of ballistic tests were carried out accelerating various geometric "fragment simulants" into an aerospace grade composite material. Damage was monitored in real time using high-speed cameras. Resulting calculations of projectile energy loss in the target, combined with analysis of recovered material via ultrasonic c-scan, have shown a clear relationship between projectile geometry and CFRP failure mode. 


\section{SUMMARY STATEMENTS}

1. It is important to know the damage mechanism in composite materials in order to produce an effective design for a structure, especially because composite materials are becoming more widely accepted and implemented in the industry.

2. Based on previous research, experimental studies, analytical formulation, and simulation have been carried out to mimic the real impact and evaluate impact damage progression.

3. In this review, only woven fabric composite plates made of synthetic composites were described. There was insufficient literature pertaining to natural fibers in the impact damage field.

4. Moreover, natural fibers have the following advantages over synthetic fibers: minimal harm to the environment, enhanced energy recovery and biodegradability, low density, high toughness, acceptable specific strength, reduced dermal and respiratory irritation, low cost, and possible applicability in the aerospace industry (though this requires additional testing).

5. Therefore, there is a critical need to examine the impact response of bio-composites and compare the differences, and general agreements, with the collected literature concerning woven fabric composite plates made of synthetic and natural fibers.

\section{ACKNOWLEDGMENTS}

This work is supported by UPM under GP-IPS 9486400. The authors would like to express their gratitude and sincere appreciation to the Aerospace Manufacturing Research Centre (AMRC) and Laboratory of Biocomposite Technology, Institute of Tropical Forestry and Forest Products (INTROP), University Putra Malaysia (HiCOE).

\section{REFERENCES CITED}

Al-mosawi, A. I., Al-Maamori, M. H., and Wetwet, Z. A. (2012). "Mechanical properties of composite material reinforcing by natural-synthetic fibers,"Academic Research International. 3(3), 108-112.

Atas, C., and Sayman, O. (2008). "An overall view on impact response of woven fabric composite plates," Compos. Struct. 82(3), 336-345. DOI: 10.1016/j.compstruct.2007.01.014

Bachtiar, D., Sapuan, S. M., Zainudin, E. S., Khalina, A., and Dahlan, K. Z. M. (2010). "Tensile properties of single sugar palm (Arenga pinnata)," 9th National Symposium on Polymetric Materials, IOP Conf. Series: Mat. Sci. \& Eng. 11. DOI: 10.1088/1757$899 \mathrm{X} / 11 / 1 / 012012$

Fisher, W. G., Meyer, K. E., Wachter, E. A., and Perl, D. R., (1997). "Laser induced fluorescence imaging of thermal damage in polymer matrix composites," Mater. Eval. 55(6), 726-729. 
Freeman, W.T. (1993). " The use of composite in aircraft primary structure," Compos. Eng. 3(7-8), 767-775. DOI: https://doi.org/10.1016/0961-9526(93)90095-2

Frieden, J., Cugnoni, J., Botsis, J., and Gmür, T. (2012). "Low energy impact damage monitoring of composites using dynamic strain signals from FBG sensors - Part I: Impact detection and localization," Compos. Struct. 94(2), 438-445. DOI: 10.1016/j.compstruct.2011.08.003

Fu, T., Liu, Y., Lau, K., and Leng, J. (2014). "Impact source identification in a carbon fiber reinforced polymer plate by using embedded fiber optic acoustic emission sensors," Compos. Part B Eng. 66, 420-429. DOI: 10.1016/j.compositesb.2014.06.004

Gbenga, E. E., (2016). "Using non-destructive testing for the manufacturing of composites for effective cost saving: A case study of a commercial Prepreg CFC," Int. Jour. of Mat. Eng. 6(2) 28-38. DOI: 10.5923/j.ijme.20160602.02

Grytten, F. (2008). "Low-velocity penetration of aluminium plates," $\mathrm{PhD}$ Thesis, Norwegian University of Science and Technology, Trondheim, Norway.

Harris, C. E., Starnes, J. H., and Shuart, M. J. (2002). "Design and manufacturing of aerospace composite structures, state-of-the-art assessment," J. Aircr. 39(4), 545-560. DOI: $10.2514 / 2.2992$

Howie, T, Shi, Z., Jang, S. H., Jen, A., Georgeso, G., and Flinn, B. (2012). “Detection of thermal damage of CFRP composites using fluorescent thermal damage probe," in Proc. of the 44th International SAMPE Tech 2012 Conference and Exhibition: Navigating the Global Landscape for the New Composites, Charleston, South Carolina. Society for the Advancement of Material and Process Engineering.

Kim, I. G., Lee, H. Y., and Kim, J. W. (2005). "Impact damage detection in composite laminates using PVDF and PZT sensor signals," J. Intell. Mater. Syst. Struct.16, 1007-1013. DOI: 10.1177/1045389X05053918

Kirkby, E., De Oliveira, R., Michaud, V., and Månson, J. A .(2011). "Impact localisation with FBG for a self-healing carbon fibre composite structure," Compos. Struct. 94(1), 8-14. DOI: 10.1016/j.compstruct.2011.07.030

Kistaiah, N., Udaya Kiran, C., Ramachandra Reddy, G., and Sreenivasa Rao, M. (2014). "Mechanical characterization of hybrid composites: A review," J. Reinforced Plastics \& Compos. 33(14), 1364-1372. DOI: 10.1177/0731684413513050

Kuang, K. S. C., Kenny, R., Whelan, M. P., Cantwell, W. J., and Chalker, P. R. (2001). "Embedded fibre Bragg grating sensors in advanced composite materials," Compos. Sci. Technol. 61(10), 1379-1387.DOI: 10.1016/S0266-3538(01)00037-9

La Rosa, A. D., Cozzo, G., Latteri, A., Recca, A., Björklund, A., Parrinello, E., and Cicala, G. (2013). "Life cycle assessment of a novel hybrid glass-hemp/thermoset composite," J. Clean. Prod., 44, 69-76. DOI: 10.1016/j.jclepro.2012.11.038

LeBlanc, M., and Measures, R. M. (1992). "Impact damage assessment in composite materials with embedded fibre-optic sensors," Compos. Eng. 2(5-7), 573-596. DOI: 10.1016/0961-9526(92)90044-7

Lee, S. G., Choi, S. S., and Park, W. H. (2003). "Characterization of surface modified flax fibers and their biocomposites with PHB,” Macromol. Symp. 89-100. DOI: 10.1002/masy.200350709

Leng, J., and Asundi, A. (2003). "Structural health monitoring of smart composite materials by using EFPI and FBG sensors," Sensors Actuators, A Phys. 103(3), 330340. DOI: 10.1016/S0924-4247(02)00429-6 
Liang, S., Guillaumat, L., and Gning, P. B. (2015). "Impact behaviour of flax/epoxy composite plates," Int. J. Impact Eng. 80, 56-64. DOI: 10.1016/j.ijimpeng.2015.01.006

Lindgren, E., Welter, J., Sathish, S., and Ripberger, E. (2006). "Detection of incipient thermal damage in polymer matric composites," Air Force Research Laboratory, United States Air Force.

Li, X., Guo, C., Liu, X., Liu, L., Bai, J., Xue, F., Lin, P., and Chu, C. (2014). "Impact behaviors of poly-lactic acid based biocomposite reinforced with unidirectional highstrength magnesium alloy wires," Prog. Nat. Sci. Mater. Int. 24(5), 472-478. DOI: 10.1016/j.pnsc.2014.08.003

Ma, L., He, L., and Zhang, L. (2017). "Effect of surface treatments on tensile properties of hemp fiber reinforced poplypropylene composites," Adv. In Ener. Sci and Env. Eng. DOI: 10.1063/1.4979748

Matadi Boumbimba, R., Froustey, C., Viot, P., and Gerard, P. (2015). "Low velocity impact response and damage of laminate composite glass fibre/epoxy based tri-block copolymer," Compos. Part B Eng. 76, 332-342. DOI: 10.1016/j.compositesb.2015.02.007

Matzkanin, G. A., and Hansen, G. P. (1999). "Heat damage in graphite epoxy composites: degradation, measurement and detection,"Johnson \& Johnson Medical Division of Ethicon, Inc.

Mazumdar, S. K. (2001). Composites Manufacturing Materials, Product, and Process Engineering, CRC Press, Boca Raton, FL, USA. DOI: $10.1201 / 9781420041989$

Mohanty, A. K., Misra, M., and Drzal, L. T. (2005). Natural Fibres, Biopolymers, and their Bio Composites, CRC Press UK. DOI: 10.1201/9780203508206

Naveen, E., Venkatachalam, N., Naveenkumaran, G., and Ramkumar, M. (2016). "Silane chemical treatment to the surface modification for the natural fiber," Adv. In Nat. \& Appl. Sci. 10(3), 224-232.

Okabe, Y., Mizutani, T., Yashiro, S., and Takeda, N. (2002). "Detection of microscopic damages in composite laminates with embedded small-diameter fiber Bragg grating sensors," Compos. Sci. Technol. 62(7-8), 951-958. DOI: 10.1016/S02663538(02)00009-X

Okabe, T., and Yashiro,S. (2012). "Damage detection in holed composite laminates using an embedded FBG sensor," Compos. Part A Appl. Sci. Manuf. 43(3), 388-397. DOI: 10.1016/j.compositesa.2011.12.009

Panopoulou, A., Loutas, T., Roulias, D., Fransen, S., and Kostopoulos, V. (2011). “Acta astronautica dynamic fiber Bragg gratings based health monitoring system of composite aerospace structures," Acta Astronaut. 69(7-8), 445-457. DOI: 10.1016/j.actaastro.2011.05.027

Pereira, G., Frias, C., Faria, H., Frazão, O., and Marques, A. T. (2013). "Study of straintransfer of FBG sensors embedded in unidirectional composites," Polym. Test. 32(6), 1006-1010. DOI: 10.1016/j.polymertesting.2013.05.006

Petrucci, R., Santulli, C., Puglia, D., Nisini, E., Sarasini, F., Tirillò, J., Torre, L., Minak, G. and Kenny, J. M. (2015). "Impact and post-impact damage characterisation of hybrid compositelaminates based on basalt fibres in combination with flax, hemp and glass fibres manufactured by vacuum infusion," Compos. Part B 69, 507-515. DOI: 10.1016/j.compositesb.2014.10.031

Pora, J. (2001). "Composite materials in the Airbus A380,from history to future," Airbus, Large Aircraft Division. 
Rajan, G., Ramakrishnan, M., Lesiak, P., Semenova, Y., Wolinski, T., Boczkowska, A., and Farrell, G. (2012). "Composite materials with embedded photonic crystal fiber interferometric sensors," Sensors Actuators, A Phys. 182, 57-67. DOI: 10.1016/j.sna.2012.05.026

Ramesh Kumar, D., and Mohanraj, P. (2017). "Review on natural fiber in various pretreatment conditions for preparing perfect fiber," Asian Jour. of Appl. Sci. and Tech. 1(2), 66-78.

Razali, N., and Sultan, M. T. H. (2014). "A novel approach for detecting, localising and characterising damages in glass fibre reinforced polymer (GFRP) using the drop weight impact tester," International Journal of Research in Engineering and Technology 03(08), 295-306. DOI: 10.15623/ijret.2014.0308047

Razali, N., Sultan, M. T. H., Safri, S. N. A., Basri, S., Yidris, N., and Mustapha, F. (2014a). "High velocity impact test on glass fibre reinforced polymer (GFRP) using a single stage gas gun (SSGG)- An experimental based approach," Appl. Mech. Mater. 564, 376-381. DOI: 10.4028/www.scientific.net/AMM.564.376

Razali, N., Sultan, M. T. H., Mustapha, F., Yidris, N., and Ishak, M. R. (2014b). "Impact damage on composites structures - A review," The Int. Jour. of Eng. And Sci. 3(7), 08-20.

Rippert, L., Wevers, M., and Van Huffel, S. (2000). "Optical and acoustic damage detection in laminated CFRP composite materials," Compos. Sci. Technol. 60(14), 2713-2724. DOI: 10.1016/S0266-3538(00)00135-4

Rogge, M. D., and Leckey, C. A. C. (2013). "Characterization of impact damage in composite laminates using guided wavefield imaging and local wavenumber domain analysis," Ultrasonics. 53(7), 1217-1226. DOI: 10.1016/j.ultras.2012.12.015

Roy, S. B., Shit, D. S. C., Sen Gupta, D. R. A., and Shukla, D. P. R. (2014). "A review on bio-composites: Fabrication, properties and applications," Int. J. Innov. Res. Sci. Eng. Technol. 03(10), 16814-16824. DOI: 10.15680/IJIRSET.2014.0310058

Santulli, C. (2007). "Impact properties of glass/plant fibre hybrid laminates," J. Mater. Sci. 42(11), 3699-3707. DOI: 10.1007/s10853-006-0662-y

Sarasini, F., Tirillo, J., A’Altilia, S., Valente, T., Santulli, C., Touchard, F., Arnault, L.C., Mellier, D., Lampani, L., and Gaudenzi, P. (2016). "Damage tolerance of carbon/flax hybrid composites subjected to low velocity impact," Comp. Part B 91. 144-153. DOI: 10.1016/j.compositesb.2016.01.050

Sarasini, F., Tirillò, J., Valente, M., Valente, T., Cioffi, S., Iannace, S., and Sorrentino, L. (2013). "Effect of basalt fiber hybridization on the impact behavior under low impact velocity of glass/basalt woven fabric/epoxy resin composites," Compos. Part A Appl. Sci. Manuf. 47(1), 109-123. DOI: 10.1016/j.compositesa.2012.11.021

Sathish, B. T., Welter, J. T., Jata, K. V., and Schehl, N. (2012). "Development of nondestructive non-contact acousto-thermal evaluation technique for damage detection in materials," Rev. Sci. Instrum. 83. DOI: 10.1063/1.4749245

Sathish, S., Welter, J., Reibel, R., and Buynak, C. (2005). "Thermo-elastic Characterization of Heat Damage in Carbon Fiber Epoxy," Compos. Rev. Prog. QNDE. 25,1015. DOI: 10.1063/1.2184636

Schrauwen, B. and Peijs, T. (2002). "Influence of matrix ductility and fibre architecture on the repeated impact response of glass-fibre-reinforced laminated composites," Appl. Compos. Mater. 9, 331-352. DOI: 10.1023/A:1020267013414 
Sudarisman, Nur Rahman, M. D., and Hidayat, A. R. (2015). "Tensile and flexural properties of bamboo (Gigantochloa apus) fiber/epoxy green composites," Appl. Mech. \& Mat. 758, 119-123. DOI: 10.4028/www.scientific.net/AMM.758.119

Sultan, M. T. H., Worden, K., Pierce, S. G., Hickey, D., Staszewski, W. J., DulieuBarton, J. M., and Hodzic, A. (2011). "On impact damage detection and quantification for CFRP laminates using structural response data only," Mech. Syst. Signal Process. 25(8), 3135-3152. DOI: 10.1016/j.ymssp.2011.05.014

Sultan, M. T. H., Worden, K., Staszewski, W. J., and Hodzic, A. (2012). "Impact damage characterisation of composite laminates using a statistical approach," Compos. Sci. Technol. 72(10), 1108-1120. DOI: 10.1016/j.compscitech.2012.01.019

Takeda, N., Okabe, Y., Kuwahara, J., Kojima, S., and Ogisu, T. (2005). "Development of smart composite structures with small-diameter fiber Bragg grating sensors for damage detection: Quantitative evaluation of delamination length in CFRP laminates using Lamb wave sensing," Compos. Sci. Technol. 65 (15-16), 2575-2587. DOI: 10.1016/j.compscitech.2005.07.014

Takeda, S., Aoki, Y., Ishikawa, T., Takeda, N., and Kikukawa, H. (2007). "Structural health monitoring of composite wing structure during durability test," Compos. Struct. 79(1), 133-139. DOI: 10.1016/j.compstruct.2005.11.057

Thakur, H. V., and Nalawade, S. M. (2011). "Polarization maintaining photonic crystal fiber sensor embedded in carbon composite for structural health monitoring," Measu rement. 44(5), 847-851. DOI: 10.1016/j.measurement.2011.01.017

Wadley, H. N. G. (2006). “ Multifunctional periodic cellular metals,” DOI: $10.1098 /$ rsta.2005.1697

Yan, Y. J., and Yam, L. H. (2002). "Online detection of crack damage in composite plates using embedded piezoelectric actuators/sensors and wavelet analysis," Compos. Struct. 58(1), 29-38. DOI: 10.1016/S0263-8223(02)00043-0

Yashiro, S., Takeda, N., Okabe, T., and Sekine, H. (2005). "A new approach to predicting multiple damage states in composite laminates with embedded FBG sensors," Compos. Sci. Technol. 65(3-4) 659-667. DOI: 10.1016/j.compscitech.2004.09.022

Yusoff, R., Takagi, H., and Nakagaito, A. N. (2016). "Tensile and flexural properties of polylactic acid-based hybrid green composites reinforced by kenaf, bamboo and coir fibers," Industrial Crops \& Products 94. 562-573. DOI: 10.1016/j.indcrop.2016.09.017

Zhang, Y., Li, Y., Ma, H., and Yu, T. (2013). "Tensile and interfacial properties of unidirectional flax/glass fiber reinforced hybrid composites," Compos. Sci. Technol., 88, 172-177. DOI: 10.1016/j.compscitech.2013.08.037

Zhou, G., and Sim, L. M. (2009). "Evaluating damage in smart composite laminates using embedded EFPI strain sensors," Opt. Lasers Eng. 47(10), 1063-1068. DOI: h10.1016/j.optlaseng.2009.03.004

Zhou, X. Y., Zheng, F., Li, H. G., and Lu, C. L. (2010). "An environment-friendly thermal insulation material from cotton stalk fibers," Energy Build., 42 (7), 10701074. DOI: 10.1016/j.enbuild.2010.01.020

Article submitted: March 22, 2016; Peer review completed: July 30, 2016; Revised version received: September 2, 2017; Accepted: September 3, 2017; Published:

September 7, 2017.

DOI: 10.15376/biores.12.4.Razali 